\title{
TRANSFERSOME GEL FORMULATION OF AN ETHANOL EXTRACT OF APPLES (MALUS DOMESTICA MILL) CONTAINING ANTIOXIDANTS AND IN VITRO PENETRATION TESTING USING FRANZ DIFFUSION CELLS
}

\author{
NURARITA FADILA ZESIORANI, EFFIONORA ANWAR*
}

Department of Pharmacy, Faculty of Pharmacy, Universitas Indonesia, Depok, Indonesia. Email: effionora@farmasi.ui.ac.id Received: 21 April 2017, Revised and Accepted: 13 July 2017

ABSTRACT

Objective: This study aims to formulate and characterize a transfersome apple peel extract, formulate it into a gel, and compare it with a control gel made without transfersome.

Methods: Both gels were evaluated, stability tested, and penetration tested using Franz diffusion cells on the skin of female Sprague-Dawley rats. The transfersome preparations were formulated with different concentrations of the active substance, quercetin: $0.5 \%$ (F1); $0.7 \%$ (F2), and 1.0\% (F3).

Results: Based on the characterization results, F1 was selected as the optimum gel formulation because it had spherical morphology, a $\mathrm{D}_{\text {mean }}$ volume of $106.44 \pm 2.70 \mathrm{~nm}$, a polydispersity index of $0.078 \pm 0.01$, a zeta potential of $-49.96 \pm 2.05 \mathrm{mV}$, and a drug efficiency entrapment percentage of $78.78 \pm 0.46 \%$. The cumulative amount of quercetin that was penetrated with the transfersome gel was $1514.41 \pm 26.31 \mu \mathrm{g} / \mathrm{cm}^{2}$, whereas the penetration with the control gel extract was $1133.62 \pm 18.96 \mu \mathrm{g} / \mathrm{cm}^{2}$. The cumulative percentages of the penetrated gel transfersome and gel extract were $78.40 \pm 1.89 \%$ and $49.89 \pm 0.88 \%$, respectively. The fluxes of transfersome gel and control gel extract were $52.33 \pm 0.11 \mu \mathrm{g} / \mathrm{cm}^{2} / \mathrm{hrs}$ and $40.89 \pm 0.68 \mu \mathrm{g} / \mathrm{cm}{ }^{2} / \mathrm{hrs}$, respectively.

Conclusions: Based on these results, it can be concluded that the gel with transfersome exhibited better penetration than the gel extract alone.

Keywords: Apple extract gel, Transfersome, Formulation.

(C) 2017 The Authors. Published by Innovare Academic Sciences PvtLtd. Thisis an open access article under the CC BYlicense (http://creativecommons. org/licenses/by/4. 0/) DOI: http://dx.doi.org/10.22159/ijap.2017.v9s1.19_24

\section{INTRODUCTION}

Currently, a number of health problems, including premature aging of the skin, are related to the formation of free radicals that bind to cells [1]. Two factors - internal factors (health, immune system, hormonal changes, and lifestyle) and external factors (ultraviolet [UV] light and pollutants) [2] - are correlated with the process of the formation-free radicals in the body. Reactive oxygen species (ROS) are tiny free radicals that are extremely reactive due to the presence of unpaired electrons on their outer surfaces. ROS are able to bind with cell/tissue components, causing damage that results in various degenerative diseases such as respiratory obstruction, arthritis, heart disease, stroke, diabetes, and cancer, as well as premature aging of the skin. To prevent such problems, antioxidants are needed to neutralize ROS [3]. The transdermal administration of antioxidants prevents or reduces free radical formation in the body [4]. Topical preparations for treatments are required to have good skin penetration properties and excellent absorption [5].

Sunscreen is a compound that effectively blocks the absorption of UV light radiation and mainly in the UV emission spectrum. Topical sunscreen preparations on the market generally have a high sun protection factor (SPF) value and are formulated using synthetic chemical compounds such as benzophenone, zinc oxide, and p-aminobenzoate, of which long-term administration could result in adverse drug reactions such as dermatitis or even melanoma 6,7]. Therefore, topical preparations that have antioxidant activity and potential as herbal sunscreens have been developed [8]. Apples (Malus domestica Mill) are one of the most popular fruits. The development of apple peel waste as a herbal material could be useful for nutraceutical preparations, such as canned fruit syrups. Apple peels contain the flavonoid quercetin and polyphenol derivates, which have antioxidant potential. The polyphenol compounds contained in apple peel are quercetin glycosides, catechin, epicatechin, procyanidin, phloridzin, phloretin glycoside, and chlorogenic acid [9].

A study on Marcetia taxifolia extract containing quercetin flavonoids at concentrations of $200 \mu \mathrm{g} / \mathrm{ml}, 500 \mu \mathrm{g} / \mathrm{ml}$, and $1000 \mu \mathrm{g} / \mathrm{ml}$ showed antioxidant activity and provided greater sun protection than $5 \%$ benzophenone [10]. Flavonoids are potent photoprotectors due to their ability to absorb UV light and are considered anti-inflammation and immunomodulatory agents [11]. In terms of the form and solubility of flavonoid compound formulations containing quercetin, to increase absorption, ethanol is typically added, as well as either fat and/or a surfactant [12]. The utilization of plant extracts as active materials in topical preparations is limited due to their poor absorption capabilities. One strategy that could be applied to increase the absorption and penetration of plant extract active agents is formulating them in a lipid-based carrier agent containing transfersomes [13]. Antioxidants derived from apple peel extract are easily oxidized, so they need to be protected by making them into vesicle forms such as transfersomes.

Transfersomes provide a carrier system that can deliver medication transdermally using hydrophilic, lipophilic, or amphiphilic compounds. Transfersomes, which absorb the active molecular medicinal compound, provide excellent dermal penetration effect. Surfactants are useful as activators and make the bilayer lipid arrangement more flexible to increase deformability [14]. The present study involves introductory research to determine whether apple peel extract (M. domestica Mill) has antioxidant activity and can provide protection from UV light. A vesicle formulation was applied to a semisolid preparation in the form of a water-containing gel to increase the skin's hydrating properties and effect optimal penetration of the skin's layers. The extract was formulated by optimizing its concentration before embedding the vesicle into the gel preparation. Penetration testing was performed in vitro using Franz diffusion cells by comparing formulations which contained extracts with and without apple peel transfersomes. 


\section{MATERIALS AND METHODS}

\section{Tools}

Analytical measurements (Sartorius, Goettingen, Germany), rotary evaporator (Hahn Shin HS-2005s- N, Bucheon, South Korea), vacuum evaporator (OSK 6513, Tokyo, Japan), vortex (Thomas Scientific, Swedesboro, USA), sonicator (Branson 3200, Danbury, USA), homogenizer (Multimix, Puchong, Malaysia), oven (Memmert, Schwabach, Germany), magnetic mixer (Boeco MSH-300, Hamburg, Germany), KLT densitometer (CAMAG, Muttenz, Switzerland), chamber (CAMAG, Muttenz, Switzerland), pH meter (Eutech Instruments pH 510, Ayer Rajah Crescent, Singapore), Brookfield viscometer (Brookfield, Waukesha, Wisconsin), polycarbonate membrane $0.1 \mu \mathrm{m}$ (Whatman GE Healthcare, Buckinghamshire, England), particle size analyzer (PSA) (Malven Zetasizer, Malvern, England), transmission electron microscope (TEM) (JEOL JEM 1400, Peabody, Massachusetts), UVvisible spectrophotometer (Shimadzu, Kyoto, Japan), Franz diffusion cells (Mitra, Bekasi, Indonesia), centrifuge (Labnet Spectrafuge 16M, Edison, New Jersey), and refrigerator (Panasonic, Jakarta, Indonesia) were used.

\section{Materials}

The materials used were phospholipon $90 \mathrm{G}$ (phosphatidylcholine with $0.1 \%$ ascorbyl palmitate, gift from Lipoid $\mathrm{GmBH}$, Ludwigshafen, Germany), apple peel extract ( $M$. domestica Mill) (Scinyu-Biotech, China), quercetin (Sigma Aldrich, Nucleos, Singapore), 96\% ethanol (Merck, Darmstadt, Germany), methanol (Merck, Darmstadt, Germany), dichloromethane (Merck, Darmstadt, Germany), 2,2-diphenyl-1picryl-hydrazyl-hydrate (DPPH) (Sigma Aldrich, Nucleos, Singapore), ascorbic acid (Brataco, Jakarta, Indonesia), demineralized water (Brataco, Jakarta, Indonesia), acetone (Merck, Darmstadt, Germany), toluene (Merck, Darmstadt, Germany), formic acid (Merck, Darmstadt, Germany), sodium hydroxide (Merck, Darmstadt, Germany), calcium dihydrogen phosphate (Merck, Darmstadt, Germany), Carbopol 940 (Lubrizol, Wan Chai, Hongkong), hydrochloric acid (HCl) (Merck, Darmstadt, Germany), magnesium powder (Merck, Darmstadt, Germany), and female Sprague-Dawley rats skin aged for 2-3 months and weighing 200-250 g (Nutrition Department, Faculty of Medicine, University of Indonesia).

\section{Flavonoid phytochemical test}

The extract was dissolved in $2 \mathrm{ml}$ of $96 \%$ ethanol, and then, $5 \mathrm{mg}$ magnesium powder and 10 drops $\mathrm{HCl}(\mathrm{p})$ were added. This mixture was allowed to stand for 2-5 minutes until the color changed. A positive quercetin result was indicated by a color change to pink [15].

\section{SPF score determination test}

Around $50 \mathrm{mg}$ of sample was measured into a $50 \mathrm{~mL}$ graduated test tube and $96 \%$ ethanol was added to the top, yielding a solution with a concentration of $1000 \mu \mathrm{g} / \mathrm{ml}$. This solution was then diluted to $500 \mu \mathrm{g} / \mathrm{ml}$ and $200 \mu \mathrm{g} / \mathrm{ml}$. Absorption spectrum of samples was analyzed using the UV-visible spectrophotometer at wavelengths of 290-400 nm using methanol as a blank. Absorption scores were noted every $5 \mathrm{~nm}$ from wavelengths of 290-320 nm. SPF scores were calculated using the Mansur equation (Formula 1, as follows):

$$
\mathrm{SPF}=\mathrm{CF} \times \sum_{290}^{320} \mathrm{EE}(\lambda) \times \mathrm{I}(\lambda) \times \operatorname{Abs}(\lambda)
$$

Formula 1: Mansur equation.

\section{Extract level determinations using the KLT densitometer}

Optimization was performed on two eluents, the acetone/acid/ toluene formulation at 7.6:5:1 and the acetic acid/ethyl alcohol/ toluene formulation at 6:2:0.8, which were measured at a wavelength of $371 \mathrm{~nm}$ [8]. The concentrations of the standard solutions used were $800 \mu \mathrm{g} / \mathrm{ml}, 700 \mu \mathrm{g} / \mathrm{ml}, 600 \mu \mathrm{g} / \mathrm{ml}, 400 \mu \mathrm{g} / \mathrm{ml}, 200 \mu \mathrm{g} / \mathrm{ml}$, and $100 \mu \mathrm{g} / \mathrm{ml}$. The extract sample solution was made at a concentration of $1000 \mu \mathrm{g} / \mathrm{ml}$ using a $96 \%$ ethanol solution, and the experiments were performed in triplicate. After a linear regression equation was obtained, the sample levels in the extract were measured using Formula 2 as follows:

$$
\text { Sample level in the extract }(\%)=\frac{\text { Measured concentration }}{\text { samplespot concentration }} \times 100
$$

Formula 2: The formula of sample levels in the extract.

Testing the antioxidant activity in the apple peel extract

The ethanol extract of tomato antioxidant activity test was performed using DPPH immersion at a concentration of $100 \mathrm{ppm}$. Vitamin C concentrations of $1,2,3,4,5,6$, and 8 ppm were used as standards for comparison. The concentrations of the extract sample solutions were 3,5 , $7,10,15$, and $20 \mu \mathrm{g} / \mathrm{ml}$. The test samples were made by adding $3 \mathrm{ml}$ from each Vitamin C concentration to $1 \mathrm{ml}$ DPPH $100 \mathrm{ppm}$. The solutions were shaken for 15 seconds, closed, and then incubated at $37^{\circ} \mathrm{C}$ for 30 minutes. Absorbance was measured at a wavelength of $517 \mathrm{~nm}$. The presence of free radical inhibition DPPH was determined using Formula 3, as follows:

$$
\text { Percentage of inhibition }(\%)=\frac{\begin{array}{l}
\text { Absorbance of control- } \\
\text { absorbance of sample }
\end{array}}{\text { absorbance of control }}
$$

Formula 3: The percentage of free radical inhibition DPPH.

\section{Transfersome formation}

Transfersomes were made using the thin-layer hydrating method. The main ingredients used in the creation of the transfersomes were phospholipon 90G (phosphatidylcholine, Lipoid GmBH) and surfactant (Span 80). In this research, three transfersome formulas were made using different active agent concentrations with phosphatidylcholine and Span 80, as shown in Table 1.

Phosphatidylcholine and Span 80 were diluted in $50 \mathrm{~mL}$ dichloromethane, and the extract was further diluted in $96 \%$ ethanol then added to a round evaporator flask and placed in the rotary evaporator at 50-150 rpm for $3 \mathrm{hrs}$ to evaporate all the solvent. The resulting thin layer that formed in the round evaporator flask was subjected to flowing $\mathrm{N}_{2}$ gas to prevent compound oxidation then placed in the refrigerator $4^{\circ} \mathrm{C}$ for $24 \mathrm{hrs}$. Hydration was performed using glass beads. The resulting suspension was transferred to an airtight container and stored at $4{ }^{\circ} \mathrm{C}$. Uniformity and particle size reduction were done using ultrasonication at an amplitude of 25 for 5 minutes.

\section{Transfersome characterization}

The transfersome was evaluated by observing its morphology using a TEM. Particle size distribution, polydispersity, and zeta potential were determined using a PSA. A deformability index test was performed using a mini extruder with a membrane size of $100 \mathrm{~nm}$, and entrapment efficiency was also determined.

\section{Making the transfersome gel}

\begin{tabular}{|c|c|c|c|}
\hline \multirow[t]{2}{*}{ Materials } & \multicolumn{3}{|c|}{ Concentrations (\%) (b/v) } \\
\hline & F1 & F2 & F3 \\
\hline Apple peel extract & $\begin{array}{l}\text { Equal to } \\
\text { quercetin } 0.5 \%\end{array}$ & $\begin{array}{l}\text { Equal to } \\
\text { quercetin } 0.7 \%\end{array}$ & $\begin{array}{l}\text { Equal to } \\
\text { quercetin 1.0\% }\end{array}$ \\
\hline Phosphatidylcholine & 4 & 4 & 4 \\
\hline Span 80 & 0.7 & 0.7 & 0.7 \\
\hline $\begin{array}{l}\text { Phosphate buffer } \\
\text { pH } 5.5\end{array}$ & Add 100 & Add 100 & Add 100 \\
\hline
\end{tabular}

The transfersome gel formulations in this study were prepared as follows: The carbomer was dispersed for $24 \mathrm{hrs}$ in a glass beaker

Table 1: Formulation of three transfersomes 
containing demineralized water and then placed in a homogenizer at a rate of $1000 \mathrm{rpm}$ with the gradual addition of propylene glycol. Triethanolamine was added to the base. A transfersome suspension of apple peel extract was added to the formed gel base (Formula 1-GT) as well as to apple peel extract dissolved in the appropriate solvent (Formula 2-GK). Both solutions were added gradually into the formed gel base and homogenized with a stirring speed of up to $1500 \mathrm{rpm}$ for 15 minutes. The ingredients of transfersome gel formula and control extract gel are shown in Table 2.

\section{Evaluation of the gel preparation}

The gel preparation was evaluated using organoleptic observation, homogeneity, $\mathrm{pH}$, determination of viscosity, and flow properties.

\section{Physical stability test}

Physical stability testing of the gel preparation involved cycling and stability testing at various temperatures such as low temperature, room temperature, and high temperature.

\section{In vitro penetration test}

First, the gum determination test (UPK) was conducted on both gel formulations using densitometric thin-layer chromatography (TLC). A calibration curve for the UPK was prepared with concentrations of $300,250,200,150,100,50$, and $25 \mu \mathrm{g} / \mathrm{ml}$ in $96 \%$ ethanol solvent, and penetration results were then determined. In vitro penetration testing was performed using Franz diffusion cells with a female Sprague-Dawley stretching skin strain of $0.13 \pm 0.1 \mathrm{~mm} \times \pm 2 \mathrm{~cm}$ wide; a membrane was placed between the donor compartment and the receptor compartment with the position of the stratum corneum facing upward. The compartment was filled with a phosphate bufferethanol $(\mathrm{pH} 7.4 ; 1: 1)$ solution at a temperature of $37 \pm 0.5^{\circ} \mathrm{C}$ and stirred at $300 \mathrm{rpm}$. Sampling was performed at 10, 30, 60, 90, 120, 180, 240, $300,360,420,480,540,600,660,720,840,960,1080,1200,1320$, and 1440 minutes. The sample results were calculated and analyzed using TLC - densitometry. Penetration values were calculated using Formula 4 as follows:

$$
\mathrm{Q}\left\{\mathrm{Cn} . \mathrm{V}-\sum_{\mathrm{i}=1}^{\mathrm{n}-1} \mathrm{C} . \mathrm{S}\right\} / \mathrm{A}
$$

Formula 4: Formula of penetration values.

Where

$Q=$ The number of cumulative samples penetrated per area of diffusion $(\mu \mathrm{g} / \mathrm{cm})$

$\mathrm{Cn}=$ Sample concentration $(\mu \mathrm{g} / \mu \mathrm{L})$ in $\mathrm{n}$-minute sampling

$\mathrm{V}=$ Franz diffusion cell volume $(14 / 15 \mathrm{~mL})$. $\sum_{\mathrm{i}=1}^{\mathrm{n}-1} \mathrm{C}=\begin{gathered}\text { Sample concentration number }(\mu \mathrm{g} / \mu \mathrm{L}) \text { from the first } \\ \text { sampling to before } \mathrm{n} \text {-minute }\end{gathered}$

$\mathrm{S}=$ Sampling volume $(3 \mathrm{~mL})$

$\mathrm{A}=$ Membrane area width $\left( \pm 2 \mathrm{~cm}^{2}\right)$.

The flux results were determined using Formula 6:

$$
J=\frac{M}{S x t}
$$

Where

$\mathrm{J}=$ Flux $\left(\mu \mathrm{g} / \mathrm{cm}^{2} . \mathrm{hr}\right)$.

$\mathrm{M}=$ Total cumulative sample passing through the membrane $(\mu \mathrm{g})$.

$\mathrm{S}=$ Diffusion area width $\left(\mathrm{cm}^{2}\right)$.

$\mathrm{T}=$ Time (hours).

\section{RESULTS AND DISCUSSION}

\section{Phytochemical flavonoids}

The phytochemicals in the extract were tested using the Shinoda reaction and applying a standard quercetin standard comparator. The result is indicated by a change in the color of the extract corresponding to the color change in the standard comparator, which is red orange as a positive result.

\section{Determination of SPF value}

The results obtained for the three concentrations show an increase in SPF value with the increasing concentration of the extract; these tests were performed in triplicate. The resulting SPF values are shown in Table 3.

\section{Antioxidant activity}

The linearity curve for the standard solutions of Vitamin C and the test solutions for the apple peel extract samples are shown in Fig. 1. The curves show $\mathrm{IC}_{50}$ values equal to $1.80 \mu \mathrm{g} / \mathrm{ml}$ and $5.22 \mu \mathrm{g} /$ $\mathrm{ml}$ for the positive Vitamin C control and for the test solution of the apple peel extract samples, respectively. The numbers for both curves are in the $<50 \mu \mathrm{g} / \mathrm{ml}$ range, indicating strong antioxidant activity.

\section{Determination of levels using densitometry TLC}

The optimization of both eluents was obtained in accordance with the sample and condition of analysis in the second eluent, that is, the toluene:acetone:formic acid (7.6:5:1) with a 3-hr saturation time in the $20 \times 20$ TLC chamber. Fig. 2 shows the difference in the optimization results for the second plate. The calibration curve for determination of the extract using the quercetin standard shows a linear regression equation, that is, $\mathrm{y}=1915.4+9.0888 \mathrm{x}$. The experiment was carried out in triplicate on samples at a concentration of $1000 \mu \mathrm{g} / \mathrm{ml}$ with an average yield of $22.647 \pm 0.19 \%$.

\section{Transfersome characterization}

The vesicle size distributions of the three transfersome formulas are shown in Table 4 . Table 5 contains the zeta potential and polydispersity index (PDI). The results show that F1 has the smallest volume means

Table 2: The formulation of transfersome gel and control extract gel

\begin{tabular}{lll}
\hline \multirow{2}{*}{ Materials } & \multicolumn{2}{l}{ Concentrations \% (b/b) } \\
\cline { 2 - 3 } & Formula 1 (GT) & Formula 2 (GK) \\
\hline Apple peel extract & Equal to & - \\
transfersome & quercetin 0.35\% & \\
Apple peel extract & - & Equal to \\
& & quercetin 0.35\% \\
Carbomer & 1.0 & 1.0 \\
Triethanolamine & 0.5 & 0.5 \\
Propylene glycol & 12.5 & 12.5 \\
Demineralized water & Add 100 & Add 100 \\
\hline
\end{tabular}

Table 3: The SPF value of apple peel extract with three different concentrations

\begin{tabular}{lll}
\hline Apple peel extract & SPF value \pm SD & Category \\
\hline $200 \mu \mathrm{g} / \mathrm{ml}$ & $7.875 \pm 0.01$ & Weak sun protection \\
$500 \mu \mathrm{g} / \mathrm{ml}$ & $19.931 \pm 0.13$ & Average sun protection \\
$1000 \mu \mathrm{g} / \mathrm{ml}$ & $38.936 \pm 0.40$ & Strong sun protection \\
\hline
\end{tabular}

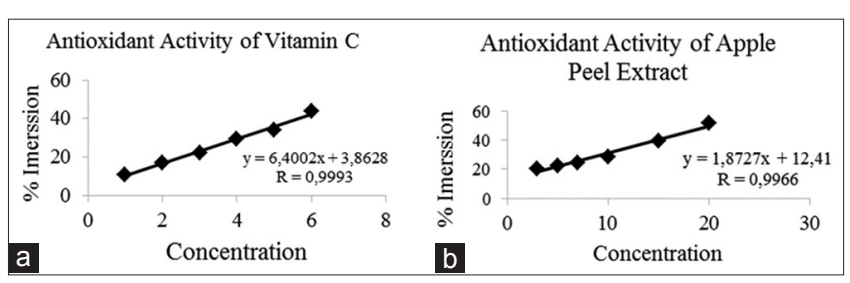

Fig. 1: ( $a$ and $b$ ) The antioxidant activity of Vitamin $C$ and apple peel extract 


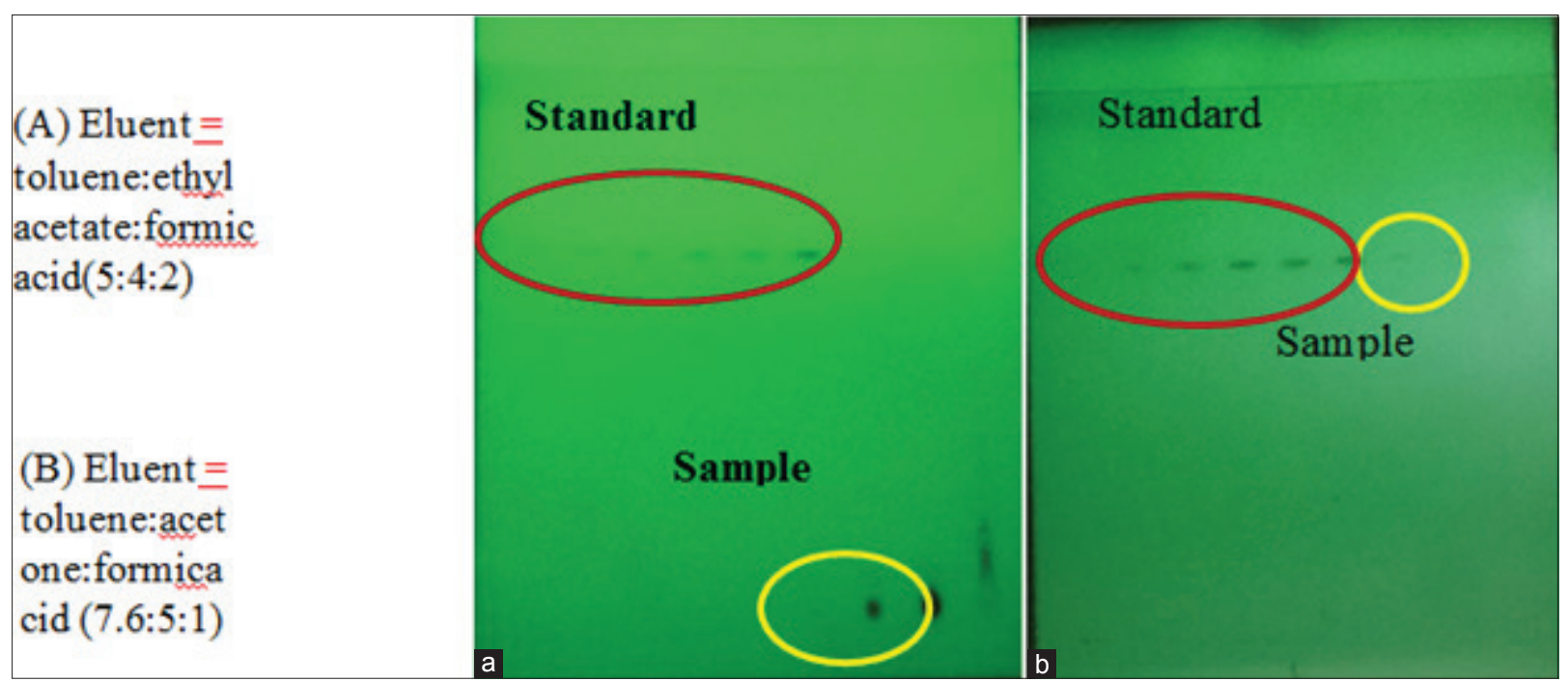

Fig. 2: ( $a$ and b) Plate image of eluent optimization observation at $365 \mathrm{~nm}$ ultraviolet rays

Table 4: Transfersome vesicle size distribution for the optimization of the three formulas

\begin{tabular}{lllll}
\hline Formula & \multicolumn{4}{l}{ Transfersome vesicle size distribution $(\mathbf{n m}) \mathbf{( m e a n} \pm$ SD) } \\
\cline { 2 - 5 } & $\mathbf{d v} \mathbf{1 0}$ & $\mathbf{d v} \mathbf{5 0}$ & $\mathbf{d v} \mathbf{9 0}$ & d mean volume \\
\hline F1 & $68.3 \pm 3.37$ & $98.9 \pm 3.55$ & $156.66 \pm 4.50$ & $106.44 \pm 2.70$ \\
F2 & $135.00 \pm 1.00$ & $175.00 \pm 0.00$ & $224.33 \pm 0.57$ & $177.04 \pm 0.22$ \\
F3 & $272.66 \pm 40.82$ & $338.33 \pm 53.79$ & $420.33 \pm 70.03$ & $340.65 \pm 54.41$ \\
\hline
\end{tabular}

Table 5: Zeta potential and polydispersity index for the optimization of the three formulas of transfersome vesicles

\begin{tabular}{lll}
\hline Sample & Polydispersity index & Zeta potential $(\mathbf{m V})$ \\
\hline F1 & $0.078 \pm 0.01$ & $-49.96 \pm 2.05$ \\
F2 & $0.273 \pm 0.09$ & $-41.93 \pm 1.51$ \\
F3 & $1.000 \pm 1.000$ & $-37.06 \pm 1.55$ \\
\hline
\end{tabular}

Table 6: Deformability index results for the three formulas of transfersome vesicles

\begin{tabular}{ll}
\hline Formulation & Deformability index \\
\hline F1 & $1.098 \pm 0.02$ \\
F2 & $2.580 \pm 0.17$ \\
F3 & $9.62 \pm 0.46$ \\
\hline
\end{tabular}

for particle sizes, which is proportional to the PDI and zeta potential, which have the best criteria. The particle size characterization results were obtained by calculating the mean D of the volume because those results are more accurate than the average particle size results. The morphological test for the vesicle form using TEM found sphericalshaped vesicles, which can be seen in Fig. 3. The three formulations are seen at 20,000× magnification.

The deformability index results for the three formulas are shown in Table 6. The deformability indexes were measured using a 100-nm membrane. These results are less representative of each formula, as the size of the extruded membrane used should be adjusted to a particle size 10 times smaller than the resulting size.

The absorption efficiency was calculated using a direct method based on the level of quercetin absorbed into the transfersome vesicles, by splitting the precipitate formed after separation at $13,000 \mathrm{rpm}$. The absorption efficiency results for the three formulas are shown in Table 7. F1 had optimum entrapment efficiency with the lowest concentration of active ingredient or extract contained in the formulation among the three formulas.

\section{Evaluation of the transfersome gel}

The $\mathrm{pH}$ measurements for the transfersome gel preparation and the control extract gel were 5.62 and 5.56, respectively. Organoleptic observations were made of the color formed in both gel preparations such as pale yellow for the transfersome gel and brownish yellow for the control gel. The second organoleptic observations of the formulations can be seen in Fig. 4. The viscosity and flow properties of the two preparations are thixotropic plastic, as shown in Fig. 5.

\section{Physical stability testing of the preparations}

Organoleptic observations at various low temperatures $\left(4 \pm 2^{\circ} \mathrm{C}\right)$ showed that, for 8 weeks, the preparations did not change color or show increases in $\mathrm{pH}$. Observations at room temperature $\left(25 \pm 2^{\circ} \mathrm{C}\right)$ showed that the transfersome preparation became brown/yellow and the control gel became brown by $4^{\text {th }}$ week, and both showed decreases in $\mathrm{pH}$. At the high temperature $\left(40 \pm 2^{\circ} \mathrm{C}\right)$, the transfersome gel changed to brown/yellow by the $4^{\text {th }}$ week and the control gel extract turned dark brown; both preparations showed decreases in $\mathrm{pH}$. The viscosities after 8 weeks of storage increased, but there were no changes in the flow properties. Fig. 6 is a graph of viscosity changes in both gel preparations after 8 weeks of storage. The shear stress when measuring the $8^{\text {th }}$ week viscosity caused a denser molecular arrangement in the gel than that of the $0^{\text {th }}$ week, resulting in a higher viscosity.

The cycling test method did not show any change of color in the preparations during storage for 6 cycles, as shown in Fig. 7.

\section{In vitro penetration test}

To obtain the calibration curve using a quercetin standard for the test determining the content (UPK) in both gel preparations and the in vitro penetration test using Franz diffusion cells, we used the equation $\mathrm{y}=$ $34.679 \times-544.6$ with an $\mathrm{R}=0.9961$. The ethanol-buffer medium (1:1) was capable of increasing the hydrophobic-shifted quercetin solubility in the receptor medium. The UPK results in the transfersome gel 
Table 7: Summary of the effectiveness of the three formulas

\begin{tabular}{|c|c|c|c|c|}
\hline $\begin{array}{l}\text { Formula } \\
\text { sample }\end{array}$ & Entrapment efficiency (\%) trial 1 & Entrapment efficiency (\%) trial 2 & Entrapment efficiency (\%) trial 3 & Mean (\%) \\
\hline $\mathrm{F} 1$ & 78.36 & 78.71 & 79.28 & $78.78 \pm 0.46$ \\
\hline $\mathrm{F} 2$ & 68.94 & 69.98 & 69.58 & $69.50 \pm 0.52$ \\
\hline F3 & 60.62 & 60.30 & 60.04 & $60.22 \pm 0.73$ \\
\hline
\end{tabular}

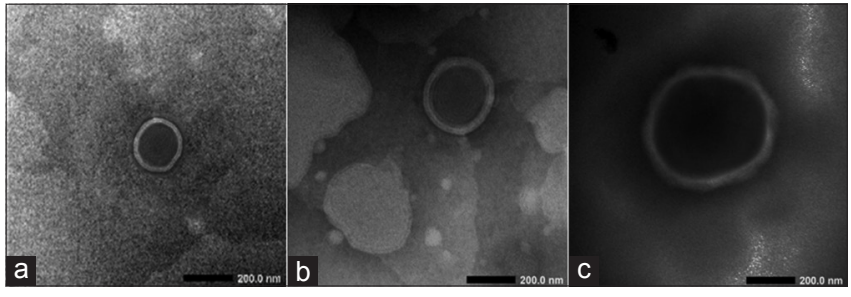

Fig. 3: Morphology of transfersome vesicles (a) F1, (b) F2, and (c) F3

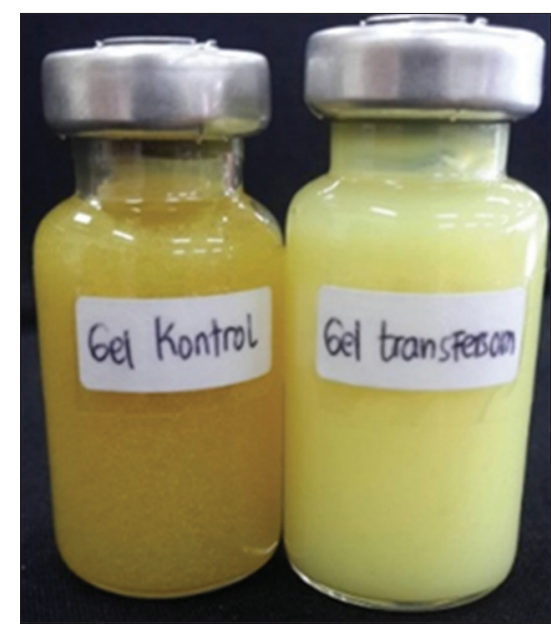

Fig. 4: Organoleptic differences between the transfersome gel and the control extract gel

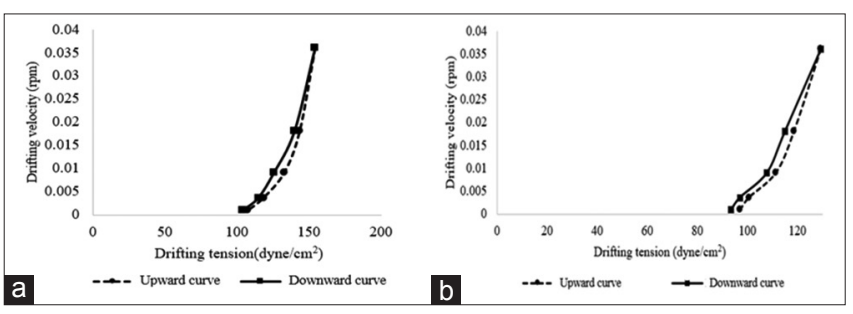

Fig. 5: ( $a$ and b) The viscosity and flow properties of the transfersome gel preparations (left) and the control gel extracts (right)

preparation and the control gel were $99.00 \pm 1.07 \%$ and $93.71 \pm 0.27 \%$, respectively. Fig. 8 shows that there was a difference in the number of penetrating between the control gel extract and the transfersome gel of $1133.624 \pm 18.96 \mu \mathrm{g} / \mathrm{cm}^{2}$ and $1514.417 \pm 26.31 \mu \mathrm{g} / \mathrm{cm}^{2}$, respectively. The percentage of quercetin penetrated from the control and transfersome gels was $78.40 \pm 1.89 \%$ and $49.89 \pm 0.88 \%$, respectively. The fluxes produced from the control gel extract and the transfersome gel were $40.891 \pm 0.68 \mu \mathrm{g} / \mathrm{cm} / \mathrm{hrs}$ and $52.337 \pm 0.11 \mu \mathrm{g} / \mathrm{cm} / \mathrm{hrs}$, respectively.

Tensile strength and elongation rate

Minimum mechanical strength for the hydrogel mask is more than $0.1 \mathrm{kgf} / \mathrm{cm}^{2}$. The tensile strength test result is $35.6524 \pm 0.8842 \mathrm{kgf} / \mathrm{cm}^{2}$,

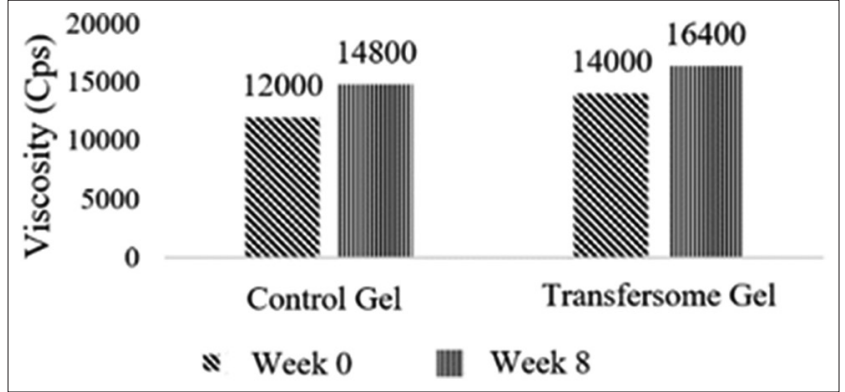

Fig. 6: Comparison of viscosity of the control gel and the transfersome gel preparations at weeks 0 and 8

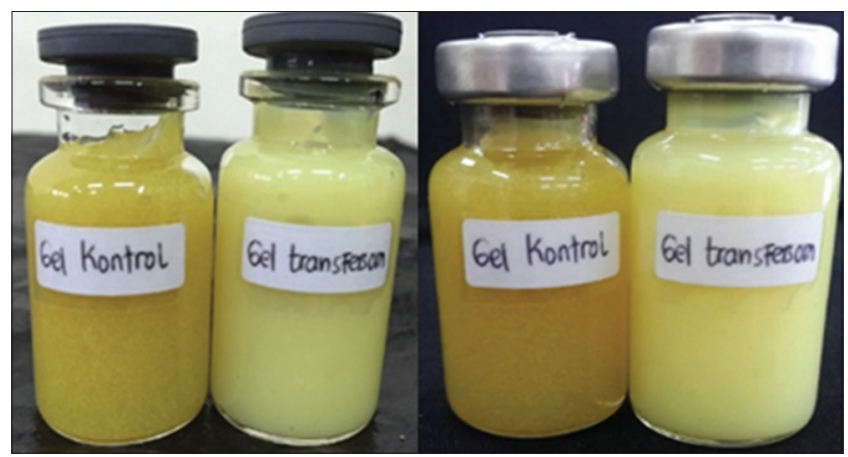

Fig. 7: Result of 6 cycles of the cycling test: Before (left) and after (right)

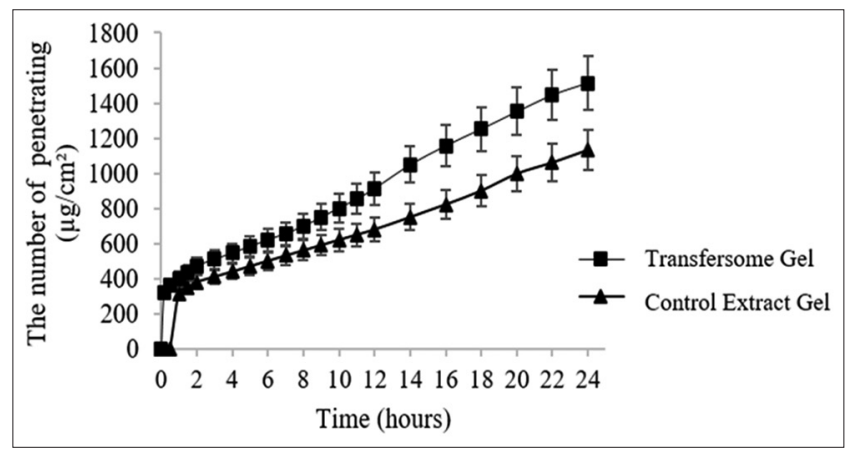

Fig. 8: The cumulative quantity of quercetin from apple peel extract penetrated per unit area of the membrane for both gel preparations

and thus, the hydrogel mask has good mechanical strength. The results of the elongation rate measurements are $272.00 \pm 4.47 \%$ demonstrating that the hydrogel mask has good elongation and elasticity.

\section{Swelling index}

The weight of the pieces increased within the second week, with a swelling index value of $113.32 \%$ (Fig. 9). The weight of the pieces increased rapidly for the first $3 \mathrm{hrs}$, with a swelling index value of $33.79 \%$ for the first hour and a swelling index value of $44.78 \%$ for the second hour (Fig. 10). The weight of the pieces increased constantly, 


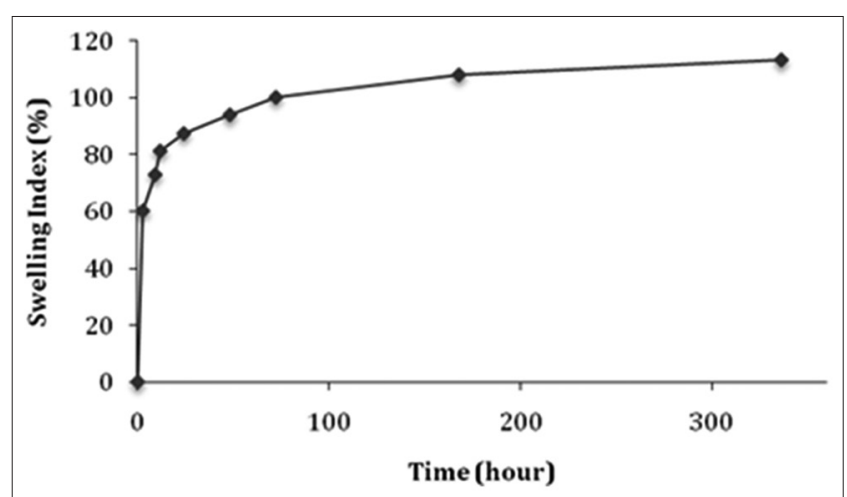

Fig. 9: Hydrogel mask swelling index in distilled water during 2-week measurement (hour 0 until hour 336)

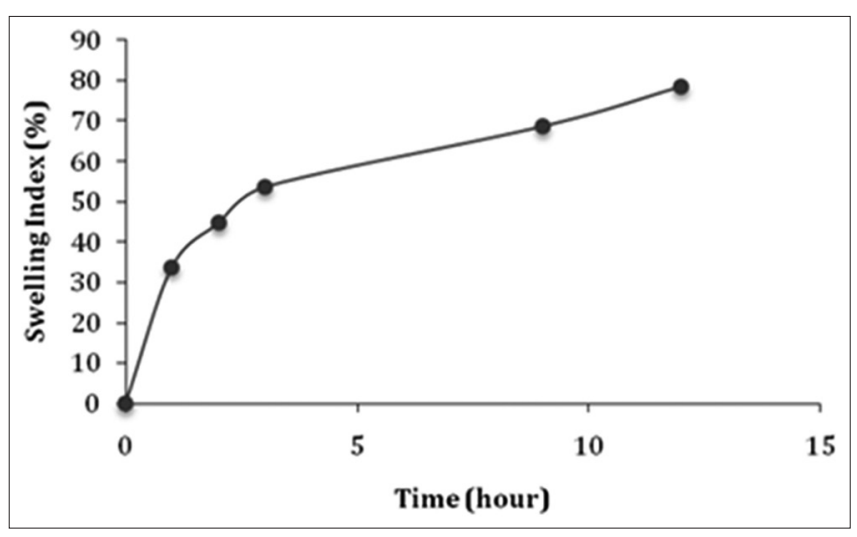

Fig. 10: Hydrogel mask swelling index in distilled water during 2-week measurement (hour 0 to hour 12)

showing that a hydrogen bond had developed and enabling the structure to swell. The hydrogel mask has good water holding capacity.

\section{Consistency}

The consistency rate was measured with a penetrometer with a cone mass of $263.6 \mathrm{~g}$. The consistency rate of the hydrogel mask was $6.03 \pm 1.53 \mathrm{~mm}$, measured when the hydrogel mask was formed. Then, on week 12 of storage, the consistency rate was $9.57 \pm 0.58 \mathrm{~mm}$, showing that the consistency of the hydrogel mask decreased during the 12-week storage in propylene glycol (Fig. 11).

\section{Hydrogel mask shrinkage}

The hydrogel mask was cut into rectangular pieces, each with an area of about $36 \mathrm{~cm}^{2}$. The initial mass used was $5.3871 \pm 0.1733 \mathrm{~g}$. Shrinkage was first observed after about 60 minutes and was measured at $35.40 \pm 0.00 \mathrm{~cm}^{2}$. It means that a condition of the hydrogel mask had not changed for about $1 \mathrm{hr}$ after the hydrogel mask was used [3]. The hydrogel mask shrinkage after $8 \mathrm{hrs}$ was $26.44 \pm 0.30 \mathrm{~cm}^{2}$, and the hydrogel mask mass continuously decreased over $8 \mathrm{hrs}$, having a final weight of $2.3562 \pm 0.0769 \mathrm{~g}$. The shrinkage was caused by water evaporation, indicating that the hydrogel mask should be storage in a sealed container.

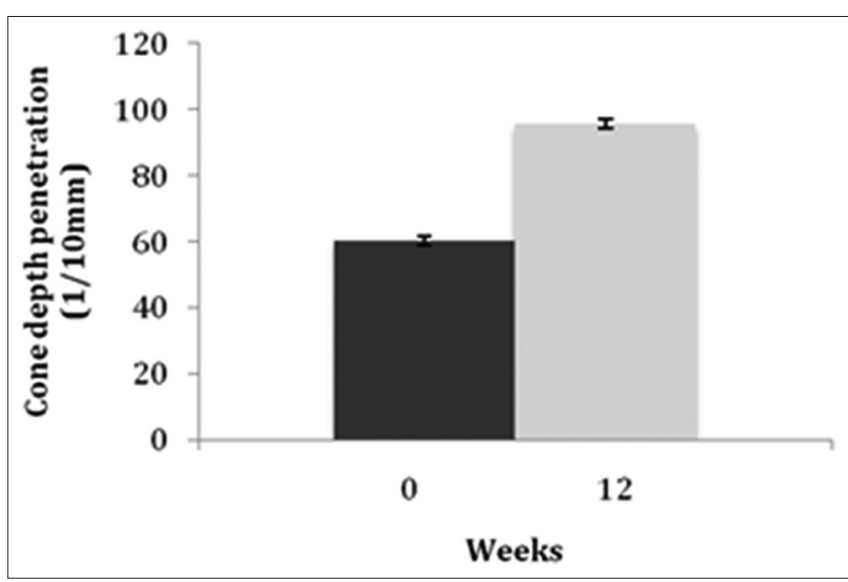

Fig. 11: Consistency of hydrogel mask when formed and on week 12 of storage

\section{CONCLUSION}

This study revealed that the hydrogel face mask containing an ethanol extract of noni fruit is stable and has good physical characteristics; therefore, the hydrogel face mask is satisfactory for use as a nutracosmeceutical product.

\section{REFERENCES}

1. Stenvinkel P, Larsson TE. Chronic kidney disease: A clinical model of premature aging. Am J Kidney Dis 2013;62(2):339-51.

2. Sen S, Chakraborty R, Sridhar C, Reddy YS, De B. Free radicals, antioxidants, diseases and phytomedicines: Current status and future prospect. Int J Pharm Sci Rev Res 2010;3(1):91-100.

3. Moore RS, Taylor DH, Reddy MM, Sturman LS, Sarma AD, Mallick AR, et al. Free radical and their role in different clinical conditions; An overview. Int J Pharm Sci Res 2010;1(3):185-92.

4. Benson HA. Transdermal drug delivery: Penetration enhancement techniques. Curr Drug Deliv 2005;2(1):23-3.

5. Widyanati P, Jufri M, Elya B. Formulation and penetration dtudy of liposome gel xanthone of extract mangosteen Pericarp (Garcinia mangostana L.). Int J Pharm Sci 2014;27(2):1-6.

6. Taufikkurohmah T. Sintesis p-metoksisinamil dari etil p-metoksisinamat hasil isolasi Rimpang kencur (Kaempferia galanga L.) sebagai Kandidat Tabir Surya. Indones J Chem 2005;5(3):193-7.

7. Deore $\mathrm{S}$, Baviskar $\mathrm{B}, \mathrm{Khadabadi} \mathrm{S}$, Nikole $\mathrm{K}$. Isolation and quantitative estimation of quercetin in Lagenaria siceraria fruit. J Chromatogr Sep Tech 2013;4(6):2-4.

8. Boyer J, Liu RH. Apple phytochemicals and their health benefits. Nutr J 2004;3:5.

9. Costa S, Detoni $\mathrm{C}$, Branco $\mathrm{C}$, Botura $\mathrm{M}$, Branco A. In vitro photoprotective effects of Marcetia taxifolia ethanolic extract and its potential for sunscreen formulations. Rev Bras Farmacogn 2015;25(4):413-8.

10. Saewan N, Jimtaisong A. Photoprotection of natural flavonoids. J Appl Pharm Sci 2013;3(9):129-41.

11. Kelly GS. Quercetin. Monograph. Altern Med Rev 2011;16(2):172-94.

12. Lipowsky R, Sackmann E. Structure and Dynamics of Membranes. $1^{\text {st }}$ ed. North Holland: Elsevier; 1995.

13. Benson HA. Transfersomes for transdermal drug delivery. Expert Opin Drug Deliv 2006;3(6):727-37.

14. Indonesian Ministry of Health. Farmakope Indonesia Edisi III. Jakarta: Korpri Sub Unit Direktorat Jenderal Pengawasan Obat dan Makanan; 1979.

15. Windono TJ, Soeratri W. Aktivitas tabir matahari etil p-metoksisinamat yang diisolasi dari rimpang kencur (Kaempferia galanga L.). News of Indones Drug 1997;38:430-1. 